\title{
Five new species of the planthopper genus Atracis Stål (Hemiptera, Fulgoromorpha, Flatidae) from China
}

\author{
Deqiang $\mathrm{AI}^{1}$, Lingfei $\mathrm{PENG}^{2}$ \& Yalin $\mathrm{ZHANG}{ }^{3, *}$ \\ 1,2,3 Key Laboratory of Plant Protection Resources and Pest Management, Ministry of Education, \\ Entomological Museum, Northwest A\&F University, Yangling, Shaanxi, 712100, P.R. China. \\ ${ }^{2}$ Key Laboratory of Integrated Pest Management for Fujian-Taiwan Crops, Ministry of Agriculture, \\ Fujian Agriculture and Forestry University, Fuzhou, Fujian, 350002, P.R. China. \\ *Corresponding author: yalinzh@nwsuaf.edu.cn \\ 1Email: aideqiang@nwafu.edu.cn \\ 2Email: lingfeipeng@fafu.edu.cn

\footnotetext{
${ }^{1}$ urn:1sid:zoobank.org:author:B8603913-50C3-479C-877F-7DF322067B08

${ }^{2}$ urn:lsid:zoobank.org:author:5FB1448D-3BED-4DC7-8CD8-F0D62DE0D7C7

${ }^{3}$ urn:lsid:zoobank.org:author:918B4F5D-D0A7-4E64-B866-5A2D94CA96B8
}

\begin{abstract}
This paper treats the planthopper genus, Atracis Stål, 1866 (Flatidae: Flatoidinae) in China. Five new species, $A$. ocularia sp. nov., A. patefacta sp. nov., A. punctulata sp. nov., A. sphaerica sp. nov. and $A$. ungulata sp. nov., are described and a checklist of all its known species from China is provided.
\end{abstract}

Keywords. Diversity, Fulgoroidea, morphology, taxonomy, Oriental region.

Ai D., Peng L. \& Zhang Y. 2020. Five new species of the planthopper genus Atracis Stål (Hemiptera, Fulgoromorpha, Flatidae) from China. European Journal of Taxonomy 717: 108-128. https://doi.org/10.5852/ejt.2020.717.1105

\section{Introduction}

The planthopper subfamily Flatoidinae Melichar, 1901 belongs together with the subfamily Flatinae Melichar, 1901 to the family Flatidae Spinola, 1839. It comprises 31 previously described genera distributed worldwide (Metcalf 1957; Bourgoin 2020). Its members are distinguished externally mainly by the tegmina positioned more or less flat, not vertically, usually more than two times as long as wide, the costal margin often undulate and the costal membrane obviously wider than the costal cell.

Currently, in the Oriental region, the subfamily Flatoidinae comprises eight genera (Atracis Stål, 1866; Bochara Distant, 1906; Cerfennia Stål, 1870; Cisatra Melichar, 1923; Gaja Distant, 1906; Malleja Medler, 1990; Ortracis Medler, 1996; Uxantis Stål, 1870), of which one is recorded from China (Fang 1989; Bourgoin 2020).

The Flatoidinae genus Atracis was established by Stål (1866) without designation of a type species. Distant (1906) studied the genus Atracis and designated Flata pyralis Guérin-Méneville, 1831 as its type species. Stål established the genus Uxantis in 1870 and did not designate a type species either (Stål 
1870). Banks (1910) considered it as a subgenus of Atracis and designated Uxantis consputa Stål, 1870 as its type species. Metcalf (1957) synonymized Franciscus Distant, 1910 and Grapaldus Distant, 1914 with the genus Atracis. Medler (1986) proposed the new name Staliana to replace Atracis and moved all the species of Atracis to it, but it was an invalid treatment (Fletcher 2009 and updates). Medler (1988) excluded from Atracis all Afrotropical species and treated Atracis as an Oriental genus.

In this paper, five new species are described and a checklist of all known species in China is provided.

\title{
Material and methods
}

The venation terminology follows Bourgoin et al. (2015), the male genitalia terminology follows Bourgoin \& Huang (1990), and the female genitalia terminology follows Bourgoin (1993). All measurements are in millimeters $(\mathrm{mm})$. The external morphology was observed under a Leica ZOOM 2000 stereo microscope. The genital segments of the examined specimens were treated with $10 \%$ $\mathrm{NaOH}$ solution at $100^{\circ} \mathrm{C}$ for several minutes, rinsed with water, immersed in 2-3 droplets of glycerol and dissected following standard procedures. They were observed under a Leica ZOOM 2000 stereo microscope. Photographs of the specimens were made using a Leica M205A microscope with a Leica DFC Camera. Images were produced using the software LAS (Leica Application Suite) ver. 3.7. Photographs were treated with Adobe Photoshop CS4. One female of A. sphaerica sp. nov. is deposited in the Beijing Natural History Museum, China (BMNHC), and two males of A. ungulata sp. nov. are deposited in the Chinese Academy of Forestry (CAF), Beijing, China or the Sun Yat-sen University (SYSU), Guangzhou, China. All other specimens are deposited in the Entomological Museum, Northwest A\&F University (NWAFU), Yangling, China.

The following measurements were used in this study:

Total length $=$ length of specimen from head apex to tegmina apex (in dorsal view)

Length of tegmen $=$ length from the base to the posterior margin of tegmen

Width of tegmen $=$ width at the widest part of tegmen

Width of costal membrane versus costal cell $=$ width of costal membrane at the widest part versus width of costal cell at the widest part

\section{Results}

\author{
Class Insecta Linnaeus, 1758 \\ Order Hemiptera Linnaeus, 1758 \\ Suborder Fulgoromorpha Evans, 1946 \\ Superfamily Fulgoroidea Latreille, 1807 \\ Family Flatidae Spinola, 1839 \\ Subfamily Flatoidinae Melichar, 1901
}

Genus Atracis Stål, 1866

Atracis Stål, 1866: 237 (type species: Flata pyralis Guérin-Méneville, 1831, by subsequent designation in Distant 1906: 450).

Uxantis Stål, 1870: 775.

Franciscus Distant, 1910: 337 (type species: Flatoides fasciatus Walker, 1870, by original designation). Grapaldus Distant, 1914: 335 (type species: Grapaldus corticinus Distant, 1914, by original designation). Staliana Medler, 1986: 18, new name for Atracis Stål, 1866 (type species: Elidiptera inaequalis Walker, 1858 , by original designation).

Atracis-Metcalf 1957: 478. 
Uxantis - Melichar 1902: 160, subgenus of Atracis Stål, 1866. - Banks 1910: 47, valid genus, designated type species: Uxantis consputa Stål, 1870 - Medler 1986: 18, synonymized.

Franciscus - Metcalf 1957: 513, synonymized.

Grapaldus - Metcalf 1957: 455, synonymized.

Staliana - Fletcher 2009 and updates, invalid new name.

\section{Distribution}

Sri Lanka, Malaysia, China (Zhejiang, Fujian, Taiwan, Guangxi and Hainan Province), India, Japan, Indonesia, Bangladesh.

\section{Checklist of species from China}

A. fimbria (Walker, 1851)

Elidiptera fimbria Walker, 1851: 331.

Flatoides fimbria (Walker) - Stål 1862: 489.

Atracis fimbria (Walker) - Melichar 1902: 199.

Distribution: China (Yunnan), India, Sri Lanka.

A. formosana Jacobi, 1915 Atracis formosana Jacobi, 1915: 177.

Distribution: China (Taiwan), Japan (Honshu, Kyushu).

A. hainanensis Distant, 1912 Atracis hainanensis Distant, 1912: 470.

Distribution: China (Hainan).

A. koshunensis Kato, 1933 Atracis koshunensis Kato, 1933: 466, fig. 2.

Distribution: China (Taiwan).

A. kotoshonis Matsumura, 1940 Atracis kotoshonis Matsumura, 1940: 48.

Distribution: China (Taiwan).

A. mucida Jacobi, 1915 Atracis mucida Jacobi, 1915: 177.

Distribution: China (Fujian, Taiwan, Hainan).

A. obscura Zia, 1935 Atracis obscura Zia, 1935: 534, fig. 5.

Distribution: China (Guangxi), India.

A. ocularia sp. nov.

Distribution: China (Hainan).

A. patefacta sp. nov.

Distribution: China (Yunnan).

A. pruinosa (Walker, 1858)

Elidiptera pruinosa Walker, 1858: 75.

Flatoides pruinosa (Walker) - Stål 1862: 489.

Atracis pruinosa - Stål 1866: 250.

Distribution: Northern China. 
A. punctulata sp. nov.

Distribution: China (Guangdong).

A. sphaerica sp. nov.

Distribution: China (Guangxi, Zhejiang).

A. ungulata sp. nov.

Distribution: China (Hainan).

\section{Key to species of Atracis in China}

1. Pronotum with three carinae A. koshunensis Kato, 1933

- Pronotum without carina 2

2. Small size, body length less than $7 \mathrm{~mm}$ A. kotoshonis Matsumura, 1940

- Medium size, body length more than $10 \mathrm{~mm}$ 3

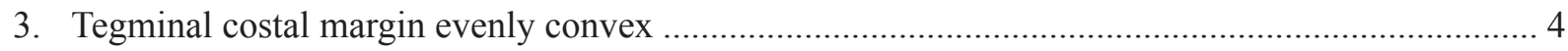

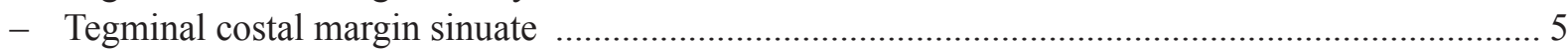

4. Vertex 1.9 times wider than long A. formosana Jacobi, 1915

- Vertex as long as wide A. obscura Zia, 1935

5. Tegmina marked with large spot (Fig. 1B) A. ocularia sp. nov.

- Tegmina variously marked but lacking large spot 6

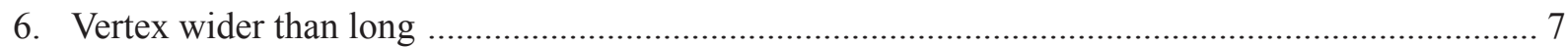

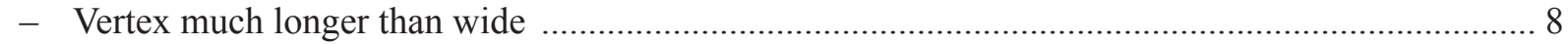

7. Vertex 1.1 times as wide as long; frons with one short carina (Fig. 8D-E) ..... A. sphaerica sp. nov.

- Vertex obviously wider than long; frons with two weak carinae. A. pruinosa (Walker, 1858)

8. Frons without longitudinal median carina A. mucida Jacobi, 1915

- Frons with short longitudinal median carina at dorsal portion 9

9. Posterior lateral margins of vertex convex or humped, higher than anterior portion 10

- Posterior lateral margins of vertex not humped, at same level as anterior portion (Fig. 3D)

A. patefacta sp. nov.

10. Head and thorax slightly mottled with dark color A. hainanensis Distant, 1912

- Head and thorax heavily marked with fuscous patches

11. Periandrium with pair of processes, apex of processes forked (Fig. 12C) A. ungulata sp. nov.

- Periandrium with pair of processes, but apex of processes not forked

12. Processes of periandrium extending ventrad and crossed

A. fimbria (Walker, 1851)

- Processes of periandrium extending cephaloventrad and parallel (Fig. 7A) ...A. punctulata sp. nov. 
Atracis ocularia sp. nov.

urn:1sid:zoobank.org:act:4A7434A6-B277-4254-B2DE-7E807E2140A8

Figs $1-2$

\section{Diagnosis}

This new species is similar to A. punctulata sp. nov., but differs from the latter by the following characters: tegmina with a large black patch (without a large patch in A. punctulata sp. nov.); costal membrane 3.2 times as wide as costal cell (4 times as wide as costal cell in A. punctulata sp. nov.); periandrium with a pair of processes, apex of processes forked (periandrium with paired processes, apex of processes not forked in A. punctulata sp. nov.).

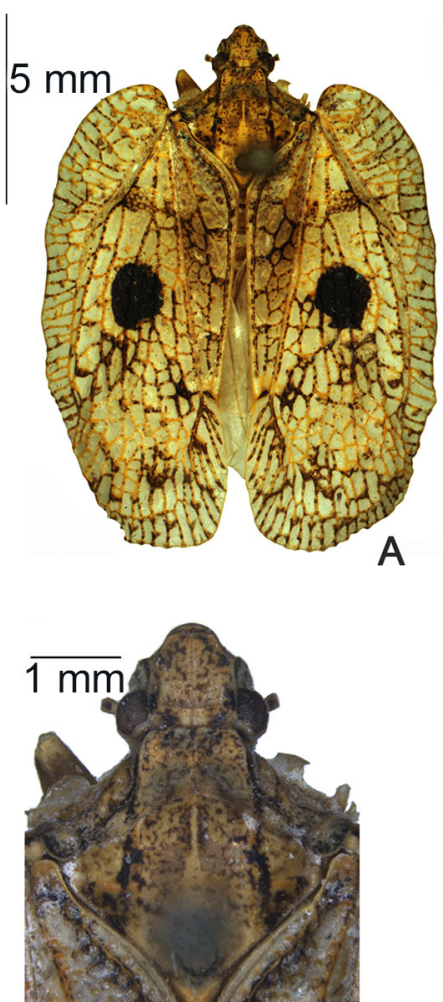

D

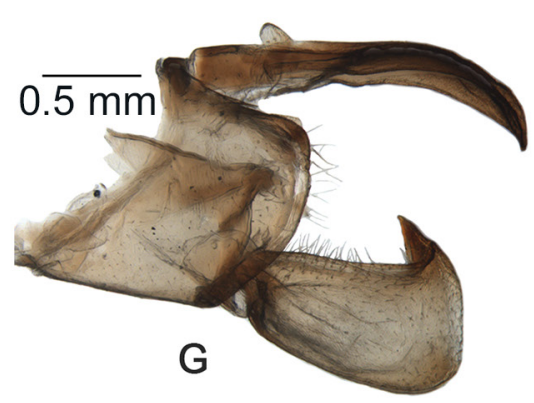

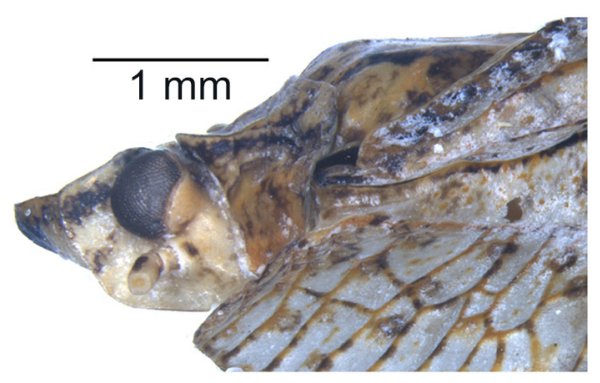

$\mathrm{E}$

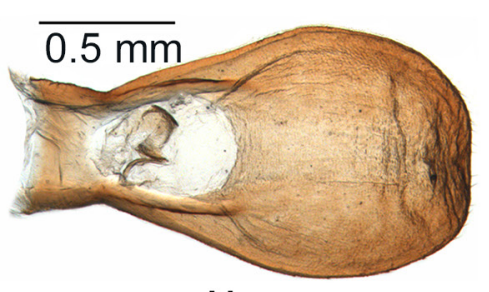

$\mathrm{H}$

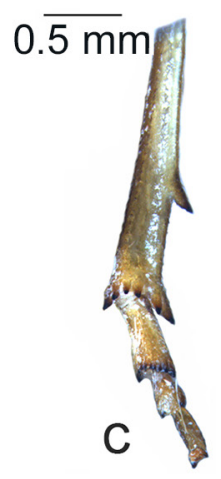

B

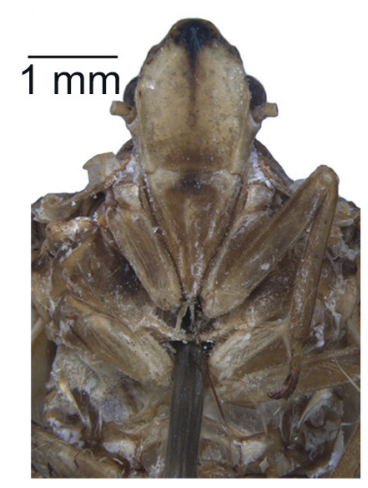

$\mathrm{F}$

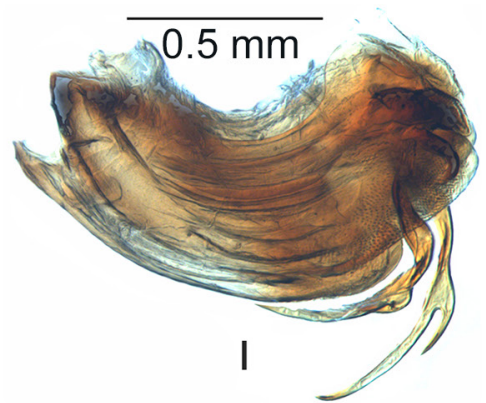

Fig. 1. Atracis ocularia sp. nov., holotype, $\widehat{\jmath}$ (NWAFU). A. Habitus, dorsal view. B. Tegmen. C. Hind leg apex. D. Head and thorax, dorsal view. E. Head and thorax, left lateral view. F. Face. G. Male genitalia (phallic complex removed), right lateral view. H. Male anal tube, dorsal view. I. Phallic complex, right lateral view. 


\section{Etymology}

The specific name is a feminine adjective 'ocularia' to emphasize a big eye shaped spot on the tegmina.

\section{Type material}

\section{Holotype}

CHINA • ${ }^{\lambda}$; Hainan Province, Mt Jianfengling; 7 May 1985; Li Weihua and Zhang Jinghong leg.; NWAFU.

\section{Description}

Measurements. Male length $(\mathrm{N}=1)$ (including tegmen): $13.5 \mathrm{~mm}$, length of tegmen: $12.1 \mathrm{~mm}$.

COLORATION. Body and tegmina yellowish brown with black markings; vertex yellowish brown marked with dark patches; frons light brown with dorsal apex and longitudinal carina black; gena yellowish
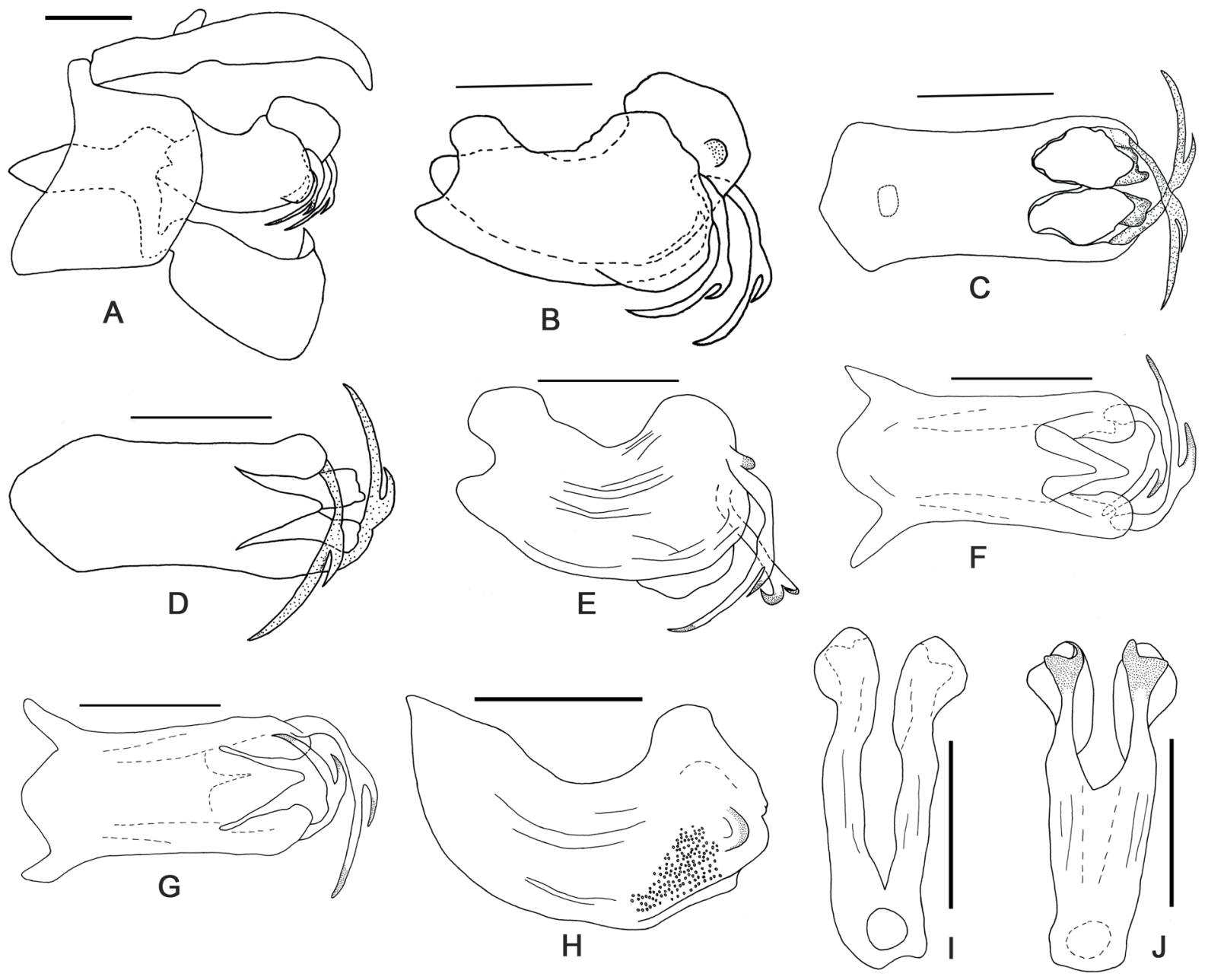

Fig. 2. Atracis ocularia sp. nov., holotype, $\widehat{O}$ (NWAFU). A. Male genitalia, right lateral view. B. Phallic complex, right lateral view. C. Phallic complex, dorsal view. D. Phallic complex, ventral view. E. Periandrium, right lateral view. F. Periandrium, dorsal view. G. Periandrium, ventral view. H. Aedeagus, right lateral view. I. Aedeagus, dorsal view. J. Aedeagus, ventral view. Scale bars $=$ $0.5 \mathrm{~mm}$. 
brown, dorsal portion and anterior portion of eye marked with darker brown color; eyes brown, ocelli milk white; dorsal apex of antennal segment II black marked; pronotum and mesonotum yellowish brown, lateral carinae black, disc mottled; tegmina yellowish brown, veins brown or black, a large black patch positioned after fork of vein MP, $1.3 \mathrm{~mm}$ in diameter (Fig. 1A-B, D-F).

HEAD AND THORAX. Head anterior margin convex; vertex pentagonal; disc pressed; longer than wide; lateral margins parallel, highly raised at posterior portion; posterior margin raised, median groove full length of vertex, apex T-forked (Fig. 1D-F). Frons disc flat, 1.3 times as long as wide, median longitudinal carina almost half length of frons, lateral margins moderately raised (Fig. 1F). Frontoclypeal suture pressed, truncate; clypeus convex. Rostrum extending beyond metatrochanter (Fig. 1F). Antennae short. Pronotum with anterior margin truncate, lateral side thick and tended up, median carina obscure, ventral margin rolled upwards, postocular eminence evenly convex (Fig. 1D-E). Mesonotum slightly humped, anterior margin convex, disc flat, without carina but lines. Metatibia with six spines apically, metatarsal basal segment with nine spines apically (Fig. 1C). Tegmina elongate, $13 \mathrm{~mm}$ in length, $5 \mathrm{~mm}$ in width; costal membrane 3.2 times as wide as costal cell at the level of bulla; costal margin undulate, apical margin convex and sinuate, sutural margin truncate, apical and sutural angles convex; vein ScP+RA elevated ridgelike above plane of vein $\mathrm{Pc}+\mathrm{CA}$ and crossing pustulate bulla, $\mathrm{CuA}$ forked, clavus and costal membrane with reticulated crossveins and pustulate; one subapical line present (Fig. 1B).

MALE Genitalia. Pygofer ring-like, anterior margin concave, posterior margin convex, dorsal and ventral margins more or less truncate (Figs 1G, 2A). Genital style ventral and apical margins convex, dorsal margin concave, with a process (Figs 1G, 2A). Male anal tube elongated, evenly bent down (Figs 1G-H, 2A). Phallic complex arched. Periandrium tubular. Dorsal part of periandrium slightly shorter than ventral part in lateral view, median lobe narrow and acute. Each side of lateral part of periandrium with forked process, recurved. Ventral part of periandrium distinctly tapering apicad in ventral view (Figs 1I, 2B-D). Aedeagus bipartite; each side of apex without process; apex of lateral portion with even prominence.

\title{
Distribution
}

Hainan Province, China.

\author{
Atracis patefacta sp. nov. \\ urn:Isid:zoobank.org:act:F084DFB5-F36E-4964-A9C2-B24260B2ECE3
}

Figs 3-5

\section{Diagnosis}

This new species looks similar to A. ungulata sp. nov., but differs from the latter by: pronotum anterior margin concave in the middle (truncate in A. ungulata sp. nov.); process of lateral lobe of periandrium not forked (forked in A. ungulata sp. nov.).

\section{Etymology}

The specific name is derived from the Latin word 'patefactus' which refers to the flat tegmina.

\section{Type material}

Holotype

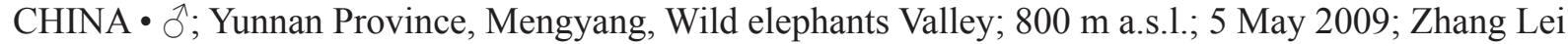
leg.; NWAFU.

\section{Paratype}

CHINA • 1 क; Yunnan Province, Banna, Menglong; 28 Apr. 1958; Meng Song County leg.; NWAFU. 


\section{Description}

Measurements. Male length $(\mathrm{N}=1)$ (including tegmen): $13.3 \mathrm{~mm}$, length of tegmen: $12.0 \mathrm{~mm}$; female length $(\mathrm{N}=1)$ (including tegmen): $15.5 \mathrm{~mm}$, length of tegmen: $13.1 \mathrm{~mm}$.
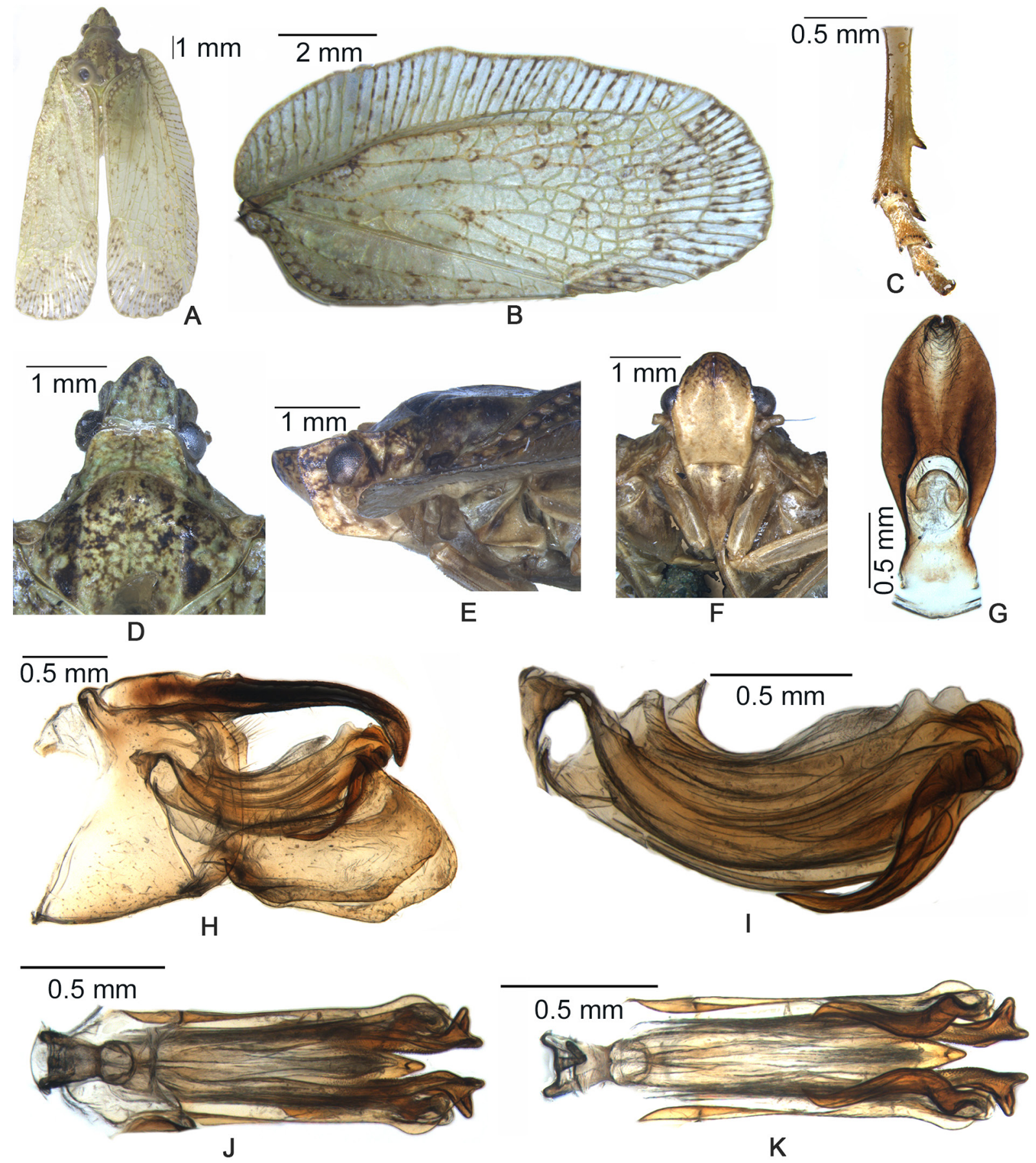

Fig. 3. Atracis patefacta sp. nov. A. Habitus, dorsal view. B. Tegmen. C. Hind leg apex. D. Head and thorax, dorsal view. E. Head and thorax, left lateral view. F. Face. G. Male anal tube, dorsal view. H. Male genitalia, right lateral view. I. Phallic complex, right lateral view. J. Phallic complex, dorsal view. K. Phallic complex, ventral view. 
Coloration. Body and tegmina green with black markings; vertex green marked with dark patches; frons light green with dorsal apex and longitudinal carina fuscous; gena yellowish green, dorsal portion and anterior portion of eye marked with darker brown color; eyes black, ocelli milk white; pronotum dull green, median carina fuscous; mesonotum dull green, heavily mottled, each posterior margin with triangular black spot; tegmina dull green, cross vein of costal area and veins of apical cell brown or black (Fig. 3A-B, D-F).

HEAD AND thORAX. Head anterior margin pointed, about $80^{\circ}$; vertex pentagonal; disc pressed; longer than wide; lateral margins slightly raised; posterior margin raised, pressed in middle; median groove full length of vertex, apex Y-forked (Fig. 3D-F). Frons disc flat, 1.4 times as wide as wide, median longitudinal carina almost half length of frons, lateral margins moderately raised (Fig. 3F). Frontoclypeal suture pressed, evenly convex; clypeus convex. Rostrum extending beyond metatrochanter (Fig. 3F). Antennae short. Pronotum with anterior margin concave in middle, disc pressed, lateral side thick and tended up, median carina obscure, ventral margin rolled upwards, postocular eminence evenly convex (Fig. 3D-E). Mesonotum humped, anterior margin convex, disc flat, without carina but lines (Fig. 3DE). Metatibia with six spines apically, metatarsal basal segment with two large spines and nine small spines apically (Fig. 3C). Tegmina elongate, $11.5 \mathrm{~mm}$ in length, $4.5 \mathrm{~mm}$ in width, costal membrane 3.8 times as wide as costal cell at level of bulla; costal margin undulate, apical margin convex and sinuate, sutural margin truncate, apical and sutural angles convex; vein ScP+RA elevated ridgelike above plane of vein $\mathrm{Pc}+\mathrm{CA}$ and crossing pustulate bulla, $\mathrm{CuA}$ forked, clavus with few crossveins; one subapical line present (Fig. 3B).

Male genitalia. Pygofer ring-like, anterior margin strongly concave, posterior margin convex, ventral margin evenly convex, dorsal margin concaved (Fig. $3 \mathrm{H}$ ). Genital style ventral and apical margins

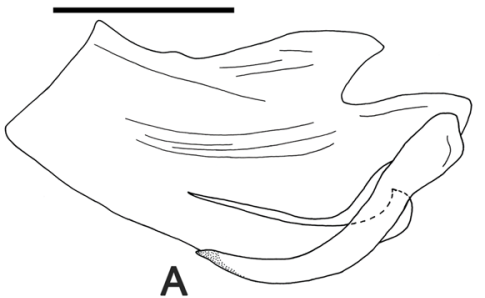

A
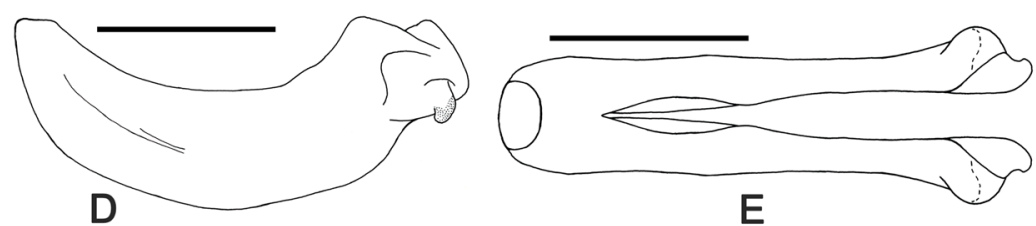

E
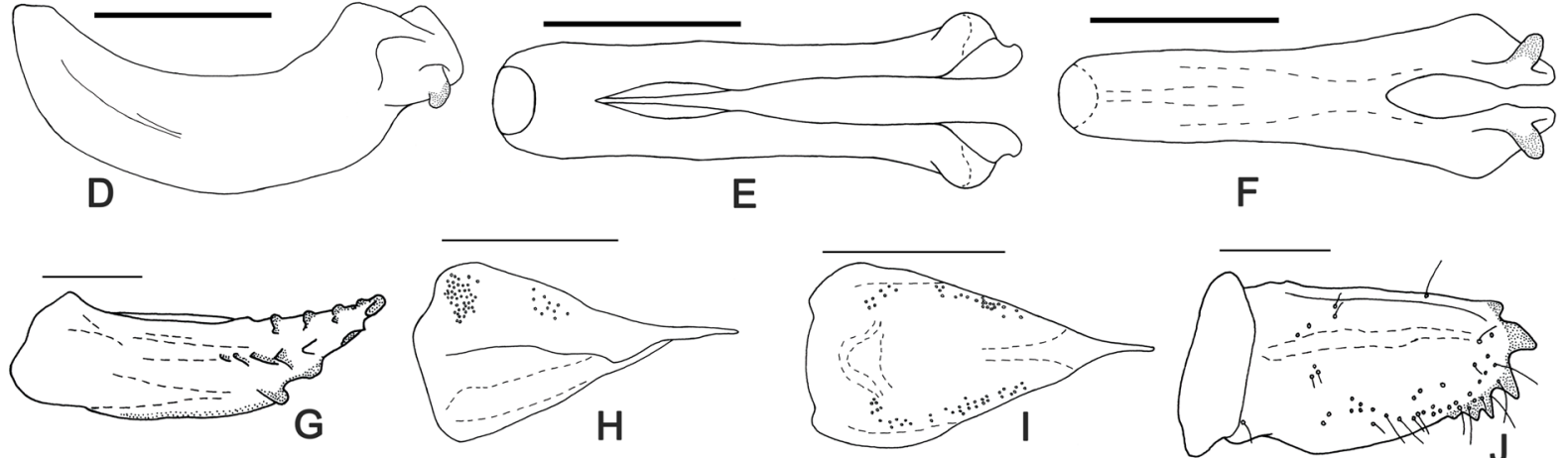

F

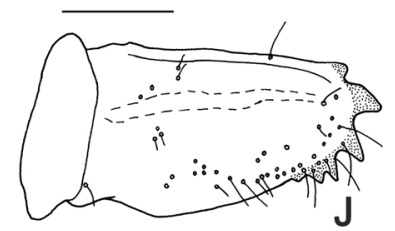

Fig. 4. Atracis patefacta sp. nov. A. Periandrium, right lateral view. B. Periandrium, dorsal view. C. Periandrium, ventral view. D. Aedeagus, right lateral view. E. Aedeagus, dorsal view. F. Aedeagus, ventral view. G. Gonapophysis VIII, right lateral outside view. H. Gonapophysis IX, right lateral view. I. Gonapophysis IX, dorsal view. J. Gonoplac, right lateral outside view. Scale bars $=0.5 \mathrm{~mm}$. 

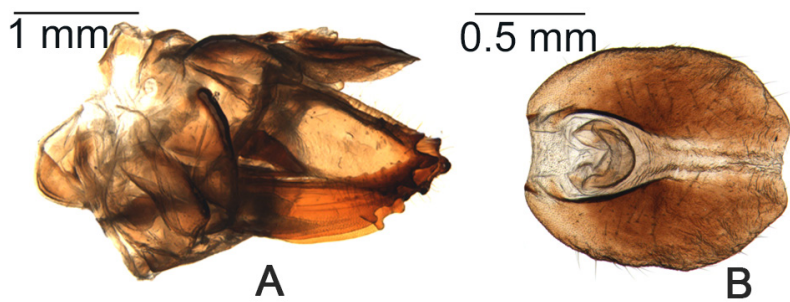

Fig. 5. Atracis patefacta sp. nov., paratype, $q$ (NWAFU). A. Female genitalia, right lateral view. B. Anal segment, dorsal view.

convex, dorsal margin concave, with a process apically (Fig. 3H). Male anal tube elongated, apex bent down (Fig. 3G-H). Phallic complex slightly arched (Fig. 3I-K). Periandrium tubular. Dorsal part of periandrium distinctly shorter than ventral part in lateral view, median lobe acute. Each side of lateral part of periandrium with recurved process, not forked. Ventral part of periandrium distinctly tapering apicad in ventral view (Fig. 4A-C). Aedeagus bipartite; each side of apex without process; apex of lateral portion with obviously raised prominence (Fig. 4D-F).

Female Genitalia. Female anal segment small, oval in dorsal view, apex slightly concave (Fig. 5B). Gonapophysis VIII slender, trangular, apex with 8 teeth, dorsal margin evenly concave, ventral margin convex (Fig. 4G); gonapophysis IX short and triangular, apex acute (Fig. 4H, I); gonoplac with arrays of strong marginal teeth (Figs 4J, 5A).

\section{Distribution}

Yunnan Province, China.

Atracis punctulata sp. nov. urn:1sid:zoobank.org:act:E27913C7-0D22-47D6-9843-7AB43A88E75A

Figs 6-7

\section{Diagnosis}

Atracis punctulata sp. nov. is similar to A. fimbria, but differs from the latter by: body and tegmina greenish and yellow (brownish in A. fimbria); disc of vertex pressed (flat in A. fimbria); preocesses of periandrium extending cephaloventrad and parallel (ventrad and crossed in A. fimbria).

\section{Etymology}

The specific name is derived from the Latin word 'punctum', which refers to the mottled color of the tegmina.

\section{Type material}

\section{Holotype}

CHINA • ${ }^{7}$; Guangdong Province, Mt Nanling; 8 May 2009; NWAFU.

\section{Description}

Measurements. Male length $(\mathrm{N}=1)$ (including tegmen): $15.1 \mathrm{~mm}$, length of tegmen: $13.1 \mathrm{~mm}$.

Coloration. Body and tegmina greenish and yellow with black markings; vertex green heavily marked with dark color; frons light greenish yellow and mottled fuscous; gena yellowish green, dorsal portion 
and anterior portion of eye marked with darker brown color; eyes black, ocelli milk white; pronotum dull green and yellow, heavily fuscous; mesonotum dark brown, marked with black spots, heavily mottled; tegmina light greenish with black markings (Fig. 6A-B, D-F).
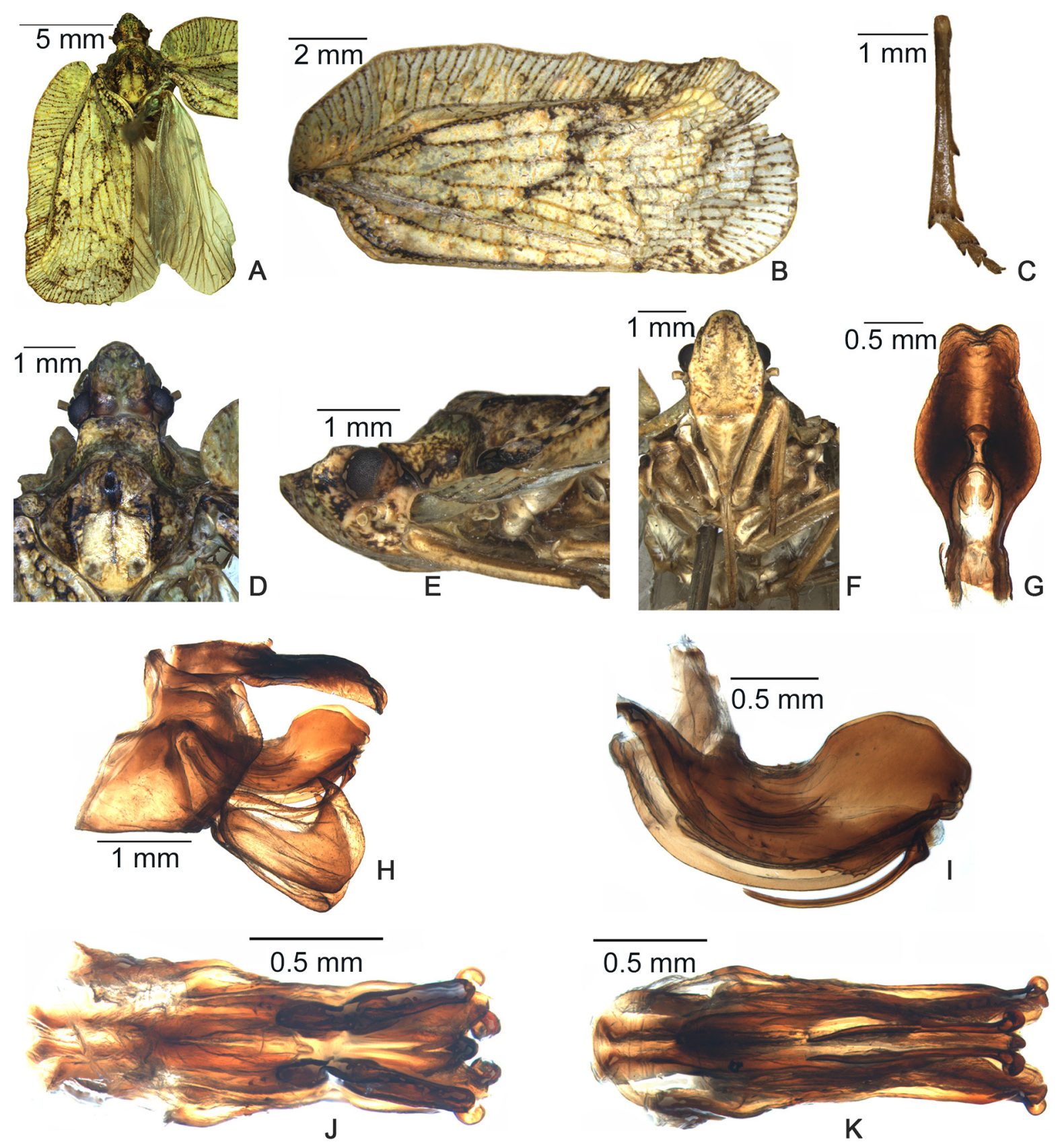

Fig. 6. Atracis punctulata sp. nov., holotype, $\widehat{\partial}$ (NWAFU). A. Habitus, dorsal view. B. Tegmen. C. Hind leg apex. D. Head and thorax, dorsal view. E. Head and thorax, left lateral view. F. Face. G. Male anal tube, dorsal view. H. Male genitalia, right lateral view. I. Phallic complex, right lateral view. J. Phallic complex, dorsal view. K. Phallic complex, ventral view. 
HeAd AND thoRAX. Head anterior margin convex, vertex pentagonal; disc pressed; as long as wide, lateral margins highly raised at posterior portion; posterior raised, pressed in the middle; median groove full length of vertex, apex Y-forked (Fig. 6D-E). Frons disc flat, 1.3 times longer than wide, median longitudinal carina no more than half length of frons, lateral carinae positioned at dorsal portion no longer than median longitudinal carina; lateral margins sinuate, highly raised (Fig. 6F). Frontoclypeal suture pressed, truncate; clypeus convex. Rostrum extending beyond metatrochanter (Fig. 6F). Antennae short. Pronotum with anterior margin truncate, slightly concave in middle, disc pressed, lateral side thick and tended up, median carina weakly raised, ventral margin rolled upwards, postocular eminence evenly convex (Fig. 6D-E). Mesonotum humped, anterior margin convex, disc flat, tricarinate (Fig. 6D-E). Metatibia with six spines apically, metatarsal basal segment with two large spines and eight small spines apically (Fig. 6C). Tegmina elongate, $13.8 \mathrm{~mm}$ in length, $6 \mathrm{~mm}$ in width, costal membrane 4 times as wide as costal cell at level of bulla; costal margin undulate, apical margin convex and sinuate, sutural margin truncate, apical and sutural angles convex; vein $\mathrm{ScP}+\mathrm{RA}$ elevated ridgelike above plane of vein $\mathrm{Pc}+\mathrm{CA}$ and crossing pustulate bulla, $\mathrm{CuA}$ forked, clavus with few crossveins; one subapical line present (Fig. 6B).

Male genitalia. Pygofer ring-like, anterior margin strongly concave, posterior margin convex and slightly sinuate, ventral margin truncate, dorsal margin concave (Fig. 6H). Genital style ventral and apical margins convex, dorsal margin concave, with a process apically (Fig. 6H). Male anal tube elongated, apex bent down (Fig. 6G-H). Phallic complex slightly arched. Periandrium tubular. Dorsal part of periandrium distinctly shorter than ventral part in lateral view, median lobe short and acute; each side of apex with three or four small teeth. Each side of lateral part of periandrium with recurved process, not forked, extending to half length of periandrium. Ventral part of periandrium distinctly slender and tapering apicad in ventral view (Figs 6I-K, 7A-C). Aedeagus bipartite; each side of apex without process; apex of lateral portion with an evenly pointed prominence (Fig. 7D-F).

\section{Distribution}

Guangdong Province, China.
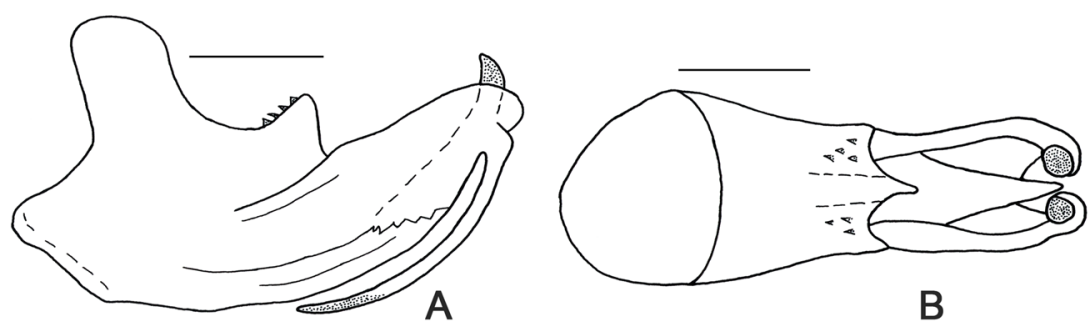

B

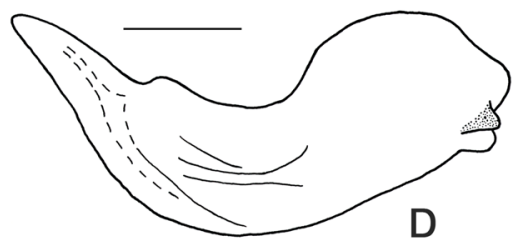

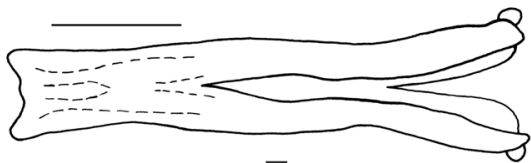

E

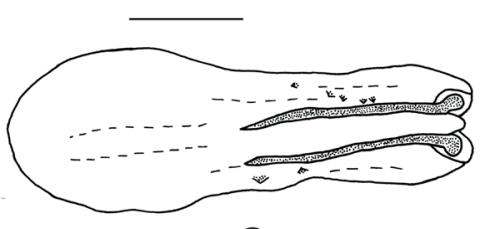

C

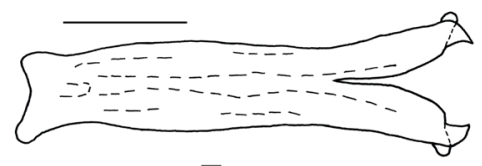

$\mathrm{F}$

Fig. 7. Atracis punctulata sp. nov. A. Periandrium, right lateral view. B. Periandrium, dorsal view. C. Periandrium, ventral view. D. Aedeagus, right lateral view. E. Aedeagus, dorsal view. F. Aedeagus, ventral view. Scale bars $=0.5 \mathrm{~mm}$. 
Atracis sphaerica sp. nov.

urn:1sid:zoobank.org:act:64303802-253F-42FC-B7F9-DD1BFFB0F3AE

Figs $8-10$

\section{Diagnosis}

This new species looks similar to $A$. mucida, but differs by: head with anterior margin angulated at about $90^{\circ}$ (slightly acute angled in $A$. mucida); vertex 1.1 times as wide as long (1.1 times as long as wide in A. mucida); frons with one obviously short median carina (median carina almost absent in A. mucida).

\section{Etymology}

The specific name is a Latin feminine adjective 'sphaerica' to refer to the globular shape of the head.
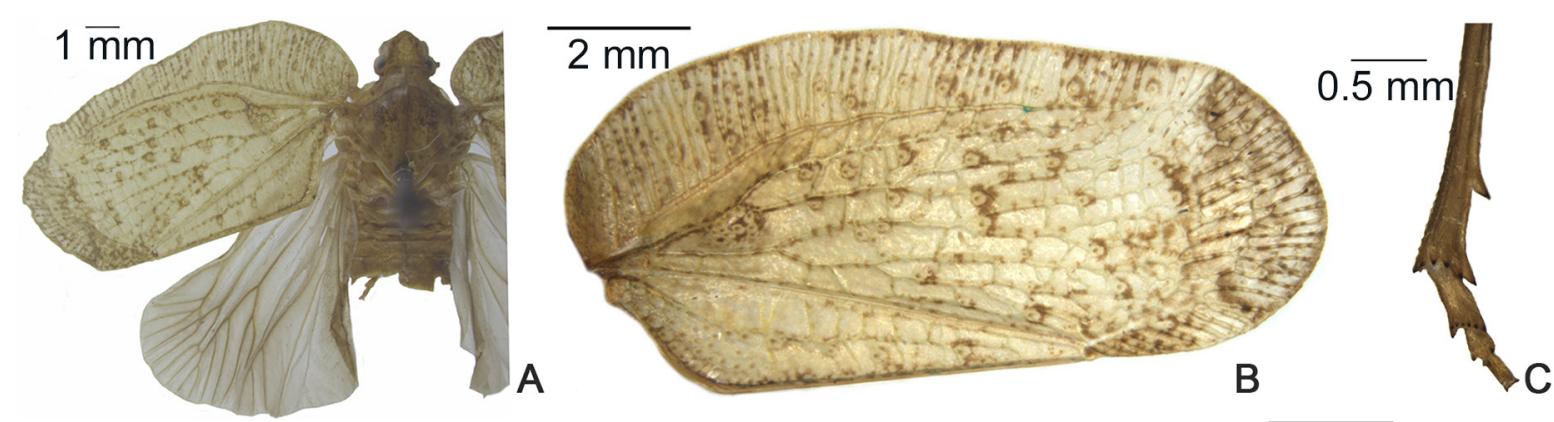

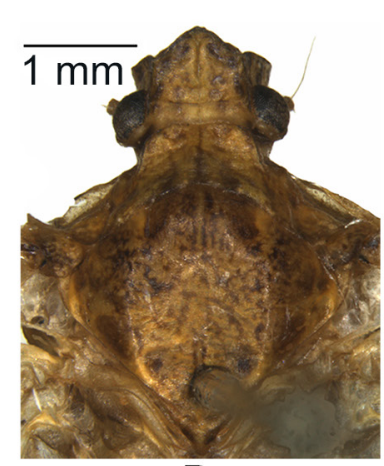

D

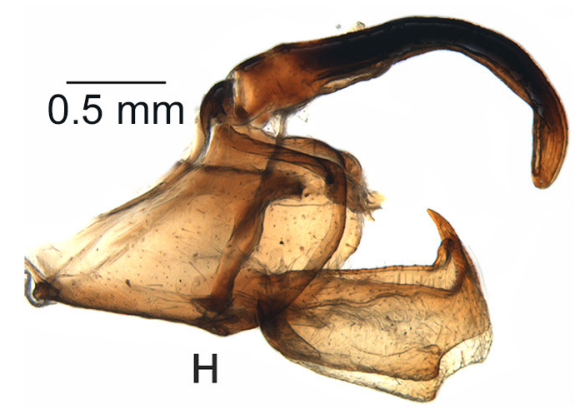

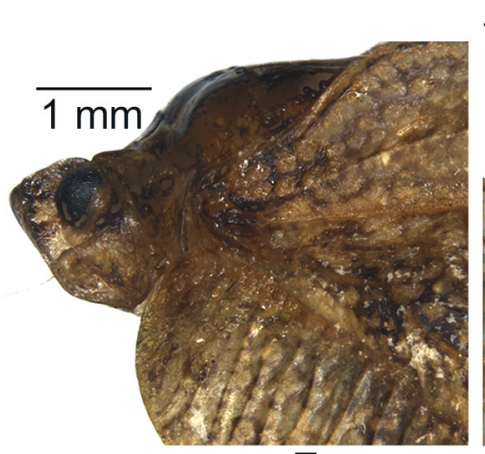

E

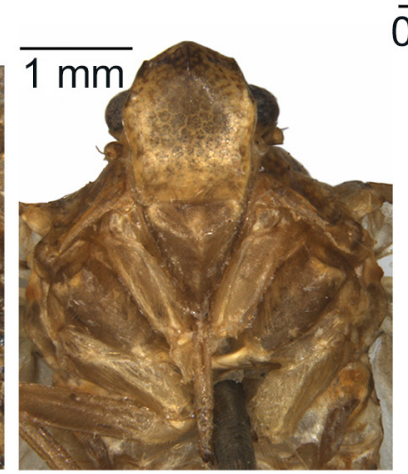

F

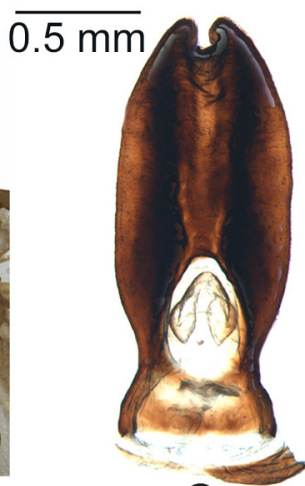

G

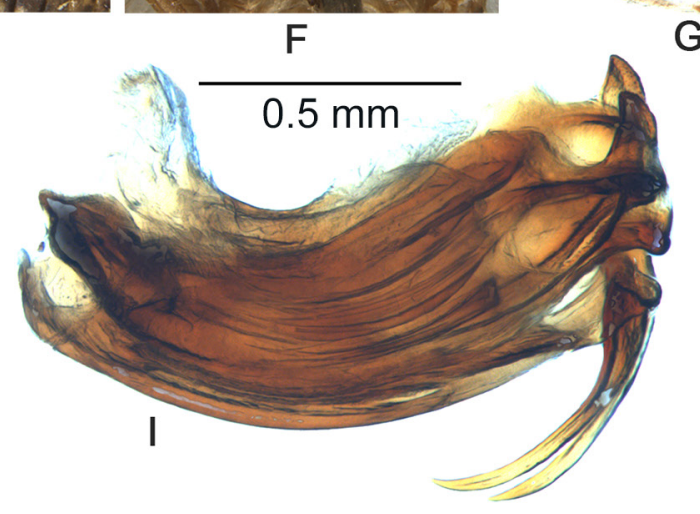

Fig. 8. Atracis sphaerica sp. nov. A. Habitus, dorsal view. B. Tegmen. C. Hind leg apex. D. Head and thorax, dorsal view. E. Head and thorax, left lateral view. F. Face. G. Male anal tube, dorsal view. H. Male genitalia (phallic complex removed), right lateral view. I. Phallic complex, right lateral view. 
AI D. et al., Five new species of the genus Atracis

\section{Type material}

\section{Holotype}

CHINA • ${ }^{7}$; Guangxi Province, Longzhou, Nonggang; 19 May 1985; Li Weihua and Zhang Jinghong leg.; NWAFU.

\section{Paratypes}

CHINA • 1 क; Guangxi Province, Mt Daqingshan; 15 Jun. 1963; Liu Sikong leg.; BMNHC • 1 क; Zhejiang Province, Mt Wuyanling; 20 Jul. 1983; Zhen Bin leg.; NWAFU.

\section{Description}

Measurements. Male length $(\mathrm{N}=1)$ (including tegmen): $14.2 \mathrm{~mm}$, length of tegmen: $11.9 \mathrm{~mm}$; female length $(\mathrm{N}=2)$ (including tegmen): $16.1-16.5 \mathrm{~mm}$, length of tegmen: $13.0-13.5 \mathrm{~mm}$.

Coloration. Body and tegmina brown with dark brown marks; vertex, pronotum and mesonotum mottled, median carina of pronotum dark brown; frons light brown with apex mottled fuscous; gena yellowish brown, dorsal portion and anterior portion of eye marked with darker brown color; eyes black,
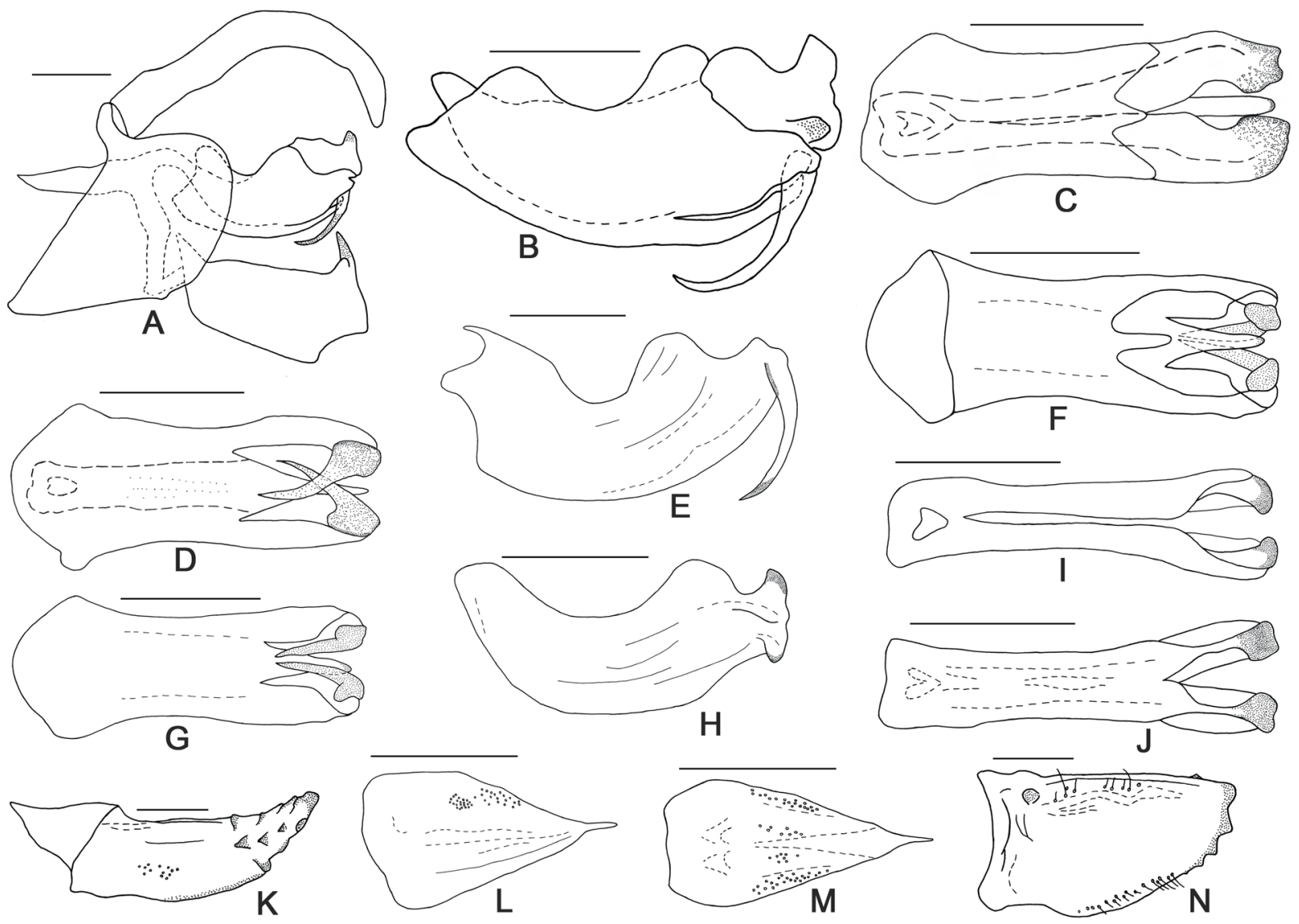

Fig. 9. Atracis sphaerica sp. nov. A. Male genitalia (phallic complex removed), right lateral view. B. Phallic complex, right lateral view. C. Phallic complex, dorsal view. D. Phallic complex, ventral view. E. Periandrium, right lateral view. F. Periandrium, dorsal view. G. Periandrium, ventral view. H. Aedeagus, right lateral view. I. Aedeagus, dorsal view. J. Aedeagus, ventral view. K. Gonapophysis VIII, right lateral outside view. L. Gonapophysis IX, lateral view. M. Gonapophysis IX, dorsal view. N. Gonoplac, right lateral outside view. Scale bars $=0.5 \mathrm{~mm}$. 
ocelli milk white; tegmina light brown, slightly transparent, marked with brown dots, apical portion and costal area dark brown (Fig. 8A-B, D-F).

HEAD AND THORAX. Head anterior margin angulated, about $90^{\circ}$; vertex pentagonal; disc pressed; 1.1 times as wide as long, lateral margins highly raised; posterior margin raised, pressed in the middle; median groove full length of vertex, apex Y-forked (Fig. 8D). Frons disc flat, 1.1 times as long as wide, median longitudinal carina very short positioned at dorsal portion, lateral margins moderately raised (Fig. 8F). Frontoclypeal suture pressed, truncate; clypeus convex. Rostrum extending to metatrochanter (Fig. 8F). Antennae short. Pronotum with anterior margin truncate, slightly concave in the middle, disc pressed, lateral side thick and tended up, median carina weakly raised, ventral margin rolled upwards, postocular eminence evenly convex (Fig. 8D-E). Mesonotum humped, anterior margin convex, disc flat, without carina (Fig. 8D-E). Metatibia with six spines apically, metatarsal basal segment with two large spines and six small spines apically (Fig. 8C). Tegmina elongate, $11.6 \mathrm{~mm}$ in length, $5 \mathrm{~mm}$ in width, costal membrane 3.5 times as wide as costal cell at level of bulla; costal margin slightly undulate, apical margin convex, sutural margin truncate, apical and sutural angles convex; vein ScP+RA elevated ridgelike above plane of vein $\mathrm{Pc}+\mathrm{CA}$ and crossing pustulate bulla, $\mathrm{CuA}$ forked, clavus with few crossveins; one subapical line present (Fig. 8B).

Male genitalia. Pygofer ring-like, anterior margin concave, posterior margin convex, ventral margin truncate, dorsal margin concave (Figs 8H, 9A). Genital style ventral, dorsal and apical margins truncate, dorsal apex with a process apically, ventral apex concave (Figs 8H, 9A). Male anal tube elongated and arched (Fig. 8G-H). Phallic complex arched (Figs 8I, 9B-D). Periandrium tubular. Dorsal part of periandrium distinctly shorter than ventral part in lateral view, median lobe narrow and acute. Each side of lateral part of periandrium with a recurved process, not forked. Ventral part of periandrium distinctly slender and tapering in ventral view (Fig. 9E-G). Aedeagus bipartite; fourth of dorsal portion apparently elevated; each side of apex without process; apex of lateral portion with a sharply short prominence (Fig. 9H-J).

Female Genitalia. Female anal segment small, oval in dorsal view, apex slightly concave (Fig. 10B). Gonapophysis VIII slender, trangular, apex with 7 teeth, dorsal margin evenly concave, ventral margin convex (Fig. 9K); gonapophysis IX short and slender, apex acute (Fig. 9L-M); gonoplac with arrays of strong marginal teeth (Figs 9N, 10A).

\section{Distribution}

Zhejiang and Guangxi Province, China.
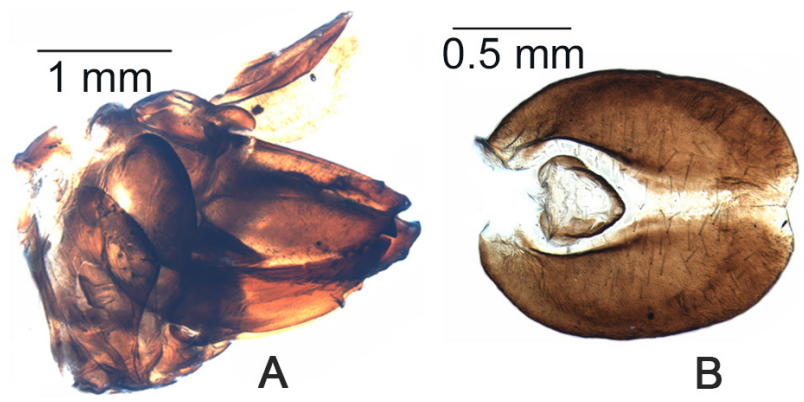

Fig. 10. Atracis sphaerica sp. nov. A. Female terminalia, right lateral view. B. Anal segment, dorsal view. 


\section{Atracis ungulata sp. nov. \\ urn:1sid:zoobank.org:act:1F84C668-54FD-4A89-8F15-F0898D4654B8}

Figs $11-12$

\section{Diagnosis}

This new species is similar to $A$. hainanensis, but differs from the latter by: vertex pentagonal (triangular in A. hainanensis); disc of vertex flat (evenly elevated in $A$. hainanensis); mesonotum without carina (tricarinate in A. hainanensis); dorsal lobe of periandrium short (long in A. hainanensis).

\section{Etymology}

The specific name is a Latin feminine adjective 'ungulata', which means a periandrium with one pair of forked processes at the apex.

\section{Type material}

\section{Holotype}

CHINA・ ○’; Hainan Province, Mt Jianfengling; 4 Apr. 1984; Lin Youdong leg.; CAF.

\section{Paratypes}

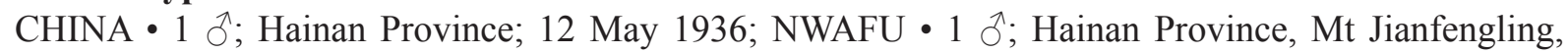
Tianchi; 30 Mar. 1982; Chen Huanqiang leg.; SYSU.
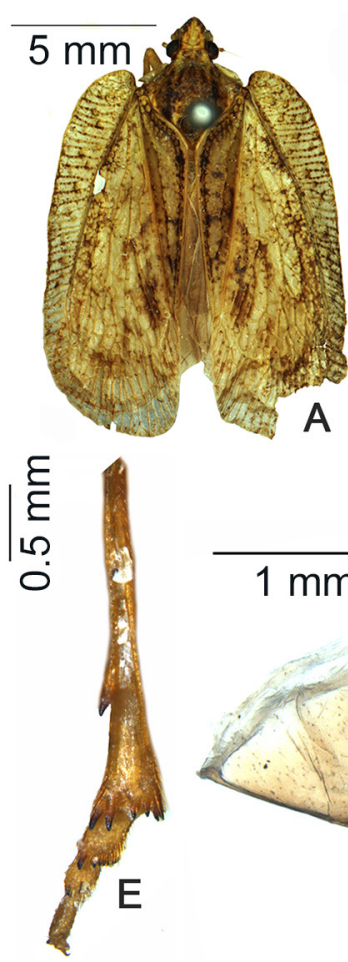

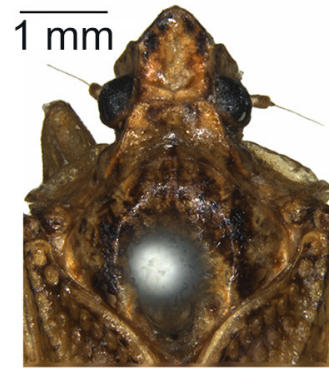

B

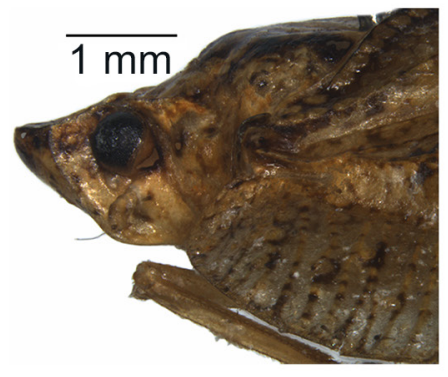

C
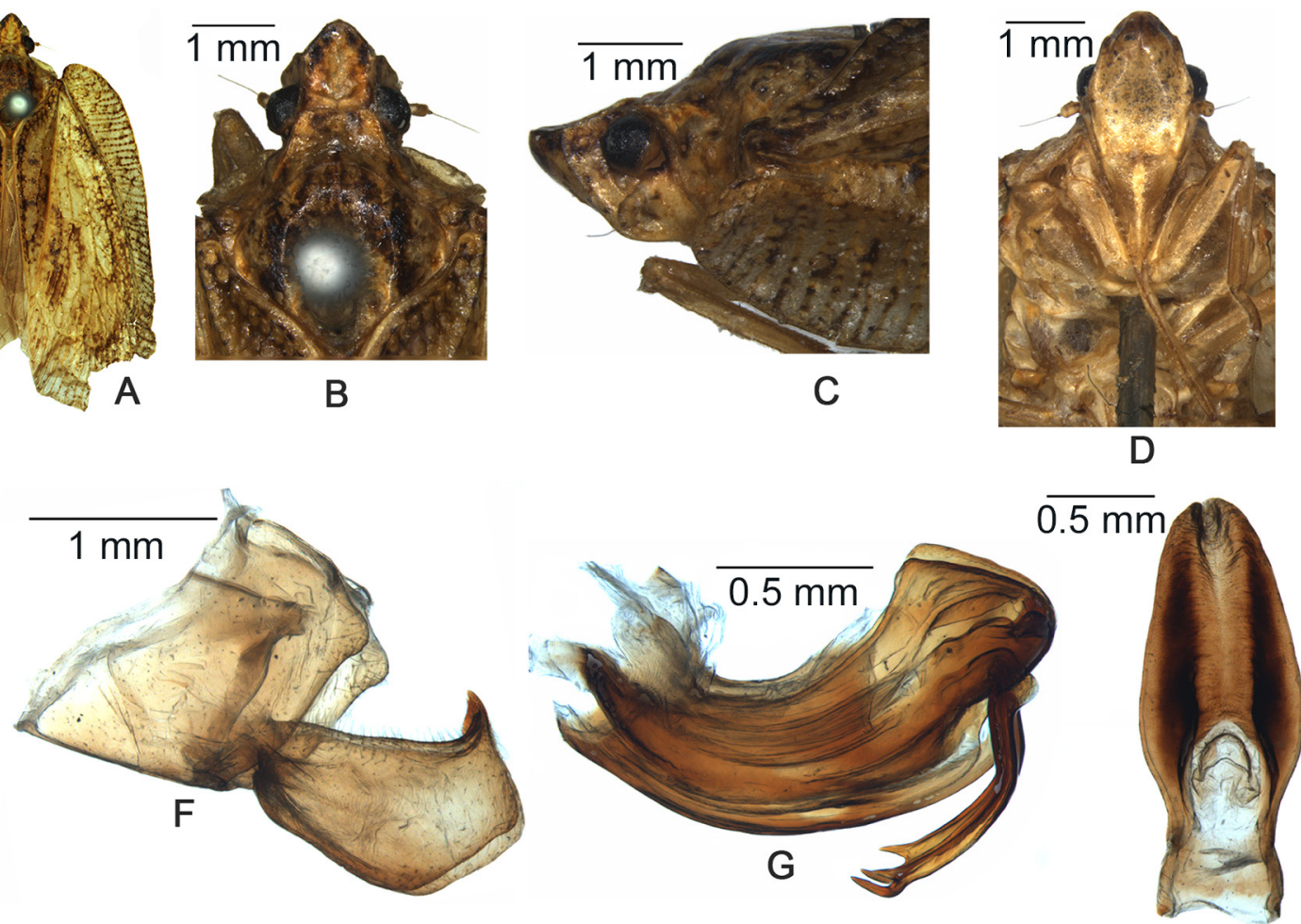

$\mathrm{H}$

Fig. 11. Atracis ungulata sp. nov. A. Habitus, dorsal view. B. Head and thorax, dorsal view. C. Head and thorax, left lateral view. D. Face. E. Hind leg apex. F. Male genitalia (male anal tube and phallic complex removed), right lateral view. G. Phallic complex, right lateral view. H. Male anal tube, dorsal view. 


\section{Description}

Measurements. Male length $(\mathrm{N}=3)$ (including tegmen): $14.7-14.9 \mathrm{~mm}$, length of tegmen: 11.9$12.1 \mathrm{~mm}$.

Coloration. Body and tegmina brown with dark brown marks; vertex, pronotum and mesonotum mottled, median carina of pronotum dark brown; frons light brown with apex mottled fuscous; gena yellowish brown, dorsal portion and anterior portion of eye marked with darker brown color; eyes black, ocelli milk white; tegmina light brown, marked with darker marks, apical portion and costal area dark brown (Fig. 11A-D).

HEAD AND THORAX. Head anterior margin angulated, about $80^{\circ}$; vertex pentagonal; disc flat; 1.1 times as long as wide, lateral margins highly raised; posterior margin raised; median groove full length of vertex, apex Y-forked (Fig. 11B-C). Frons disc flat, 1.4 times as long as wide, median longitudinal carina very short positioned at dorsal portion, lateral margins slightly sinuate, moderately raised (Fig. 11D).
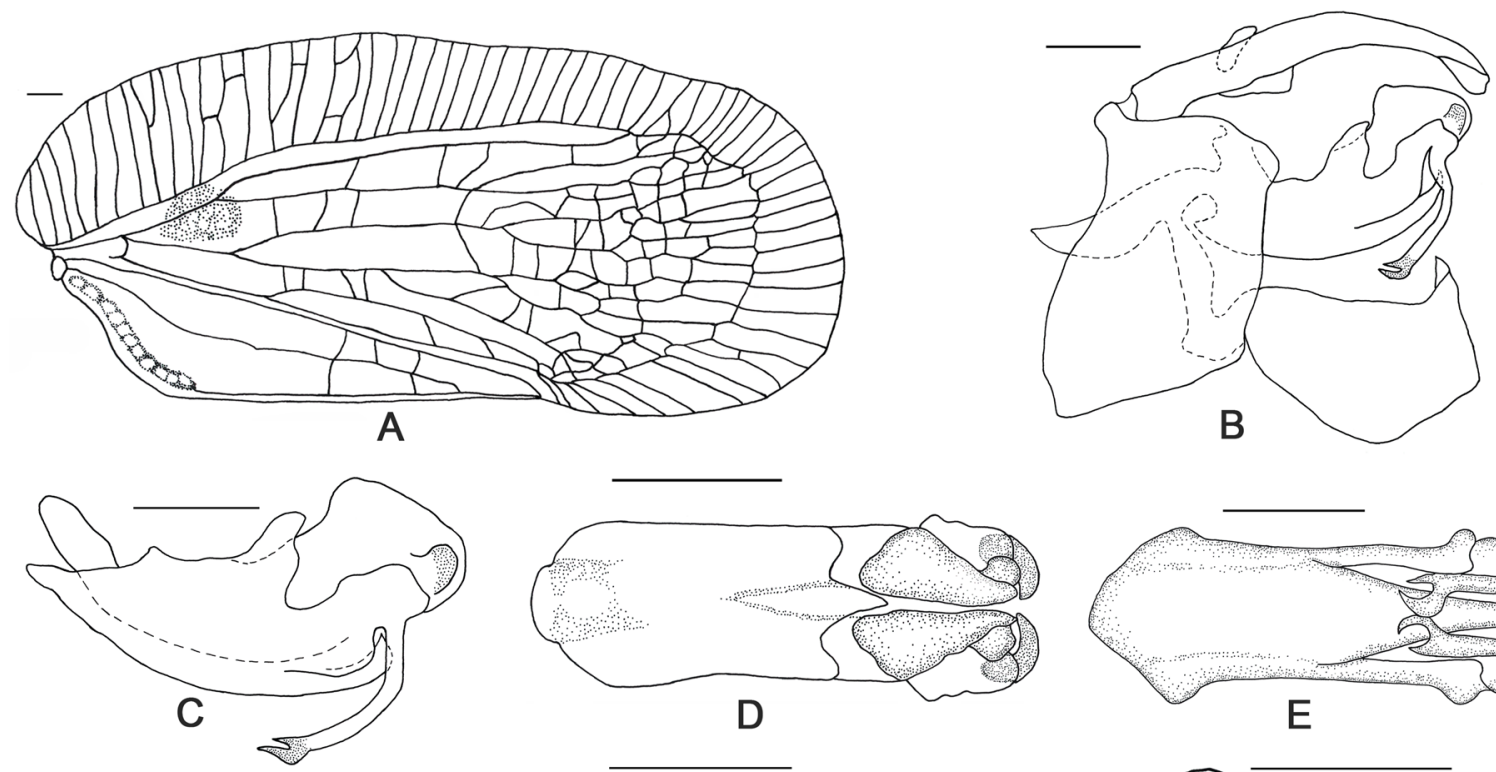

D

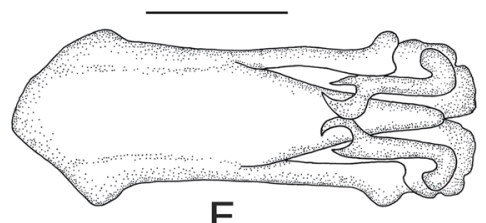

$\mathrm{E}$
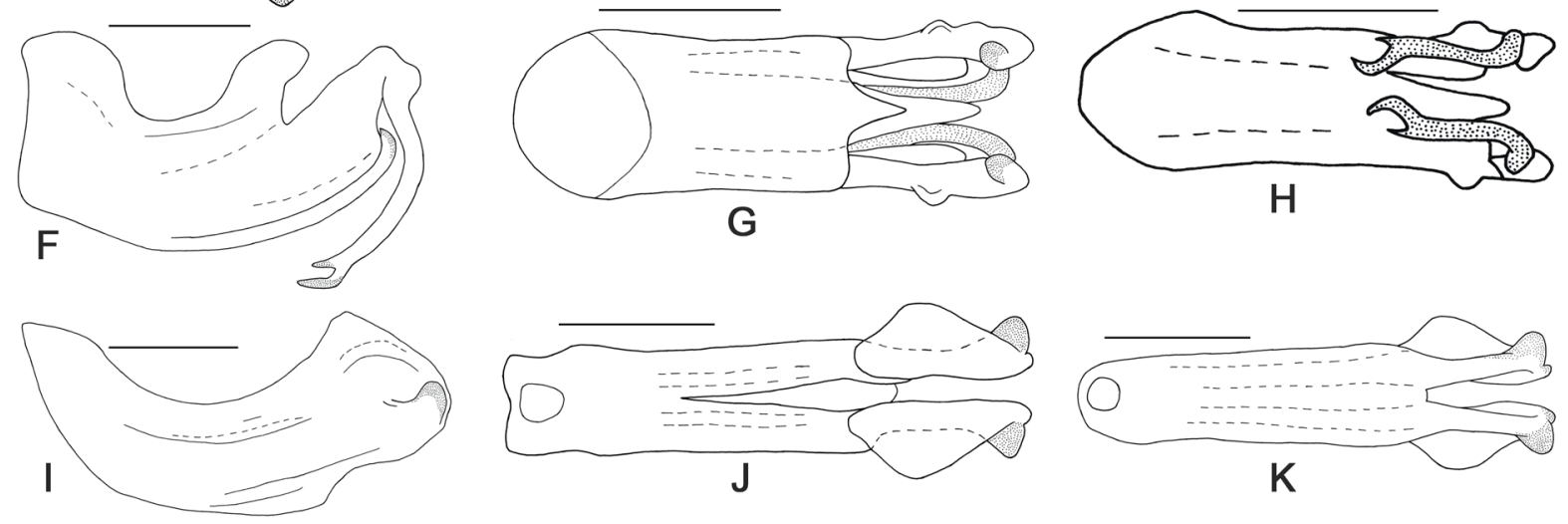

Fig. 12. Atracis ungulata sp. nov. A. Tegmen. B. Male genitalia, right lateral view. C. Phallic complex, right lateral view. D. Phallic complex, dorsal view. E. Phallic complex, ventral view. F. Periandrium, right lateral view. G. Periandrium, dorsal view. H. Periandrium, ventral view. I. Aedeagus, right lateral view. J. Aedeagus, dorsal view. K. Aedeagus, ventral view. Scale bars $=0.5 \mathrm{~mm}$. 
Frontoclypeal suture pressed, convex, clypeus convex. Rostrum extending beyond metatrochanter (Fig. 11D). Antennae short. Pronotum anterior margin truncate, disc pressed, lateral side thick and tended up, median carina weakly raised, ventral margin rolled upwards, postocular eminence evenly convex (Fig. 11B-C). Mesonotum humped, anterior margin convex, disc flat, without carina (Fig. 11BC). Metatibia with six spines apically, metatarsal basal segment with two large spines and seven or eight small spines apically (Fig. 11E). Tegmina elongate, $12.9 \mathrm{~mm}$ in length, $5.4 \mathrm{~mm}$ in width, costal membrane 3.5 times as wide as costal cell at level of bulla; costal margin evenly convex, very weak undulated, apical margin convex, sutural margin truncate, apical and sutural angles convex; vein ScP+RA elevated ridgelike above plane of vein $\mathrm{Pc}+\mathrm{CA}$ and crossing pustulate bulla, $\mathrm{CuA}$ forked, clavus with few crossveins; one subapical line present (Fig. 12A).

MALE GENITALIA. Pygofer ring-like, anterior and posterior margins sinuate, ventral margin truncate, dorsal margin sinuate (Figs 11F, 12B). Genital style ventral margin convex, dorsal margin weakly concave with process apically (Figs 11F, 12B). Male anal tube elongated and arched (Figs 11H, 12B). Phallic complex arched (Figs 11G, 12C-E). Periandrium tubular. Dorsal part of periandrium distinctly shorter than ventral part in lateral view, median lobe short and acute. Each side of lateral part of periandrium with recurved process which apex forked. Ventral part of periandrium distinctly slender and tapering in ventral view (Fig. 12F-H). Aedeagus bipartite; each side of apex without process; apex of lateral portion with ear-like prominence (Fig. 12I-K).

\section{Distribution}

Hainan Province, China.

\section{Discussion}

Male genitalia are usually regarded as the most important morphological characters in the taxonomical study of Flatidae. Based on the morphological characters, Medler $(1990,1993,1996,1999)$ and Fang (1989) illustrated the male genitalia for species of Atracis, as did for the five new species described in this paper and the specimens examined in China. It is clear that species of Atracis from China, India, Sri Lanka, Indonesia, Brunei and Malaysia are several species-groups that can be separated. Specifically, based on the characters of the phallic complex, the first species-group has more than one pair of processes of the phallic complex; the apex of the phallic complex has acute processes and the length of the process of the lateral part of the periandrium is longer than half the length of the phallic complex (A. jangis Medler, 1999, A. servis Medler, 1999, A. taenia Schmidt, 1904). The second species-group has one pair of processes of the phallic complex; the apex of the phallic complex is evenly rounded without process; the length of the process of lateral part of periandrium is slightly shorter than half length of the phallic complex (A. fimbria, A. hainanensis, A. nodosa Gerstaecker, 1895, A. ocularia sp. nov., A. patefacta sp. nov., A. sphaerica sp. nov., A. ungulata sp. nov.). The third species-group has one pair of processes of phallic complex; the apex of the phallic complex is evenly rounded without a process and the length of the process of the lateral part of the periandrium is longer than half the length of the phallic complex (A. lurida Melichar, 1902, A. mucida, A. obscura, A. punctulata sp. nov.). The first species-group is distributed in Indonesia, while the other two species-groups are distributed in China, India, Sri Lanka and Indonesia. Meanwhile, the pygofer of A. taenia in Indonesia is the most specialized one, approximately triangular; the pygofer of the other 13 species is nearly quadrilateral. Hence, we infer that the species of Atracis distributed in Indonesia maybe the most specialized one and the species of Atracis indicate a complex diversity. However, the phylogenetical relationships within Atracis are still not quite clear. In the future, it will be necessary to address the systematic analysis of Atracis from morphological, molecular and biogeographical approaches, and to clarify interspecific relationships within the genus. 


\section{Acknowledgements}

We are sincerely grateful to Prof. J.R. Schrock (Department of Biological Sciences, Emporia State University, USA) for revising the manuscript. We would like to thank Prof. Masami Hayashi (Laboratory of Entomology, Tokyo University of Agriculture, Atsugi, Japan) for private communication and providing references. We also appreciate Senior Researcher Liu Sikong (Beijing Natural History Museum) and Prof. Cai Wanzhi (China Agricultural University, Beijing) for the loan of specimens. Special thanks go to Prof. Wang Yinglun for valuable comments and suggestion on the revision of the manuscript. We thank the anonymous reviewers for their time and helpful comments on an earlier draft of this paper. This study is supported by the National Natural Science Foundation of China (31420103911) and the Ministry of Science and Technology of China (2015FY210300, 2005DKA21402).

\section{References}

Banks C.S. 1910. Rhynchota Palawanica. Part 2. Homoptera. Philippine Journal of Science 5: 33-55.

Bourgoin T. 1993. Female genitalia in Hemiptera Fulgoromorpha, morphological and phylogenetic data. Annales de la Société entomologique de France 29 (3): 225-244.

Bourgoin T. 2020. FLOW (Fulgoromorpha Lists on The Web): a world knowledge base dedicated to Fulgoromorpha. Version 8, updated [17 Feb. 2020]. Available from https://hemiptera-databases.org/flow/ [accessed 17 Feb. 2020].

Bourgoin T. \& Huang J. 1990. Morphologie comparée des genitalia mâles des Trypetimorphini et remarques phylogénétiques (Hemiptera: Fulgoromorpha: Tropiduchidae). Annales de la Société entomologique de France 26 (4): 555-564.

Bourgoin T., Wang R.R., Asche M., Hoch, H., Soulier-Perkins A., Stroiński A., Yap S. \& Szwedo J. 2015. From micropterism to hyperpterism: recognition strategy and standardized homology-driven terminology of the forewing venation patterns in planthoppers (Hemiptera: Fulgoromorpha). Zoomorphology 134 (1): 63-77. https://doi.org/10.1007/s00435-014-0243-6

Distant W.L. 1906. The Fauna of British India, including Ceylon and Burma. Rhynchota. - Vol. III. (Heteroptera-Homoptera). Published under the authority of the Secretary of State for India in Council, London.

Distant W.L. 1910. Rhynchota Malayana. Part III. Records of the Indian Museum 5: 313-338. https://doi.org/10.5962/bhl.part.10506

Distant W.L. 1912. XLVIII.- New genera and species of Oriental Homoptera. Annals and Magazine of Natural History, Series 89 (52): 459-471. https://doi.org/10.1080/00222931208693156

Distant W.L. 1914. XLVII.- Some additions to the genera and species in the Homopterous family Fulgoridae. Annals and Magazine of Natural History, Series 813 (76): 409-424.

https://doi.org/10.1080/00222931408693503

Fang S.J. 1989. Flatidae of Taiwan (Homoptera, Fulgoroidea). Collected Papers on Homoptera of Taiwan, Taiwan Museum Special Publication 8: 117-152.

Fletcher M.J. 2009 and updates. Identification keys and checklists for the leafhoppers, planthoppers and their relatives occurring in Australia and neighbouring areas (Hemiptera: Auchenorrhyncha). Available from https://idtools.dpi.nsw.gov.au/keys/auch/index.html [accessed 8 Sep. 2020].

Jacobi A. 1915. Kritische Bemerkungen über die Flatinae (Rhynchota Homoptera). Berliner entomologische Zeitschrift 1915 (2): 157-178. https://doi.org/10.1002/mmnd.191519150206

Kato M. 1933. Notes on Japanese Homoptera, with descriptions of one new genus and some new species. The Entomological World 1: 452-471. 
Matsumura S. 1940. Homopterous insects collected at Kotosho (Botel Tobago) Formosa, by Mr. Tadao Kano. Insecta Matsumurana 15 (1-2): 34-51.

Medler J.T. 1986. Types of Flatidae (Homoptera). XII. Taxonomic notes on Guerin-Meneville types in the Naples Museum, with illustrations of male genitalia of plesiotypes for the respective species. Bollettino del Laboratorio di entomologia agraria Filippo Silvestri Portici 43: 11-20.

Medler J.T. 1988. Flatidae from the Tai Forest, Cote d'Ivoire, and taxonomic notes on the family in west Africa (Homoptera, Auchenorrhyncha, Fulgoroidea). Revue Française d'entomologie 10 (2): 117-148.

Medler J.T. 1990. Review of Jamella Kirkaldy and Malleja, gen. nov. in Australia and New Guinea, with descriptions of new species (Homoptera: Flatidae). Invertebrate Taxonomy 3 (7): 995-1004.

https://doi.org/10.1071/IT9890995

Medler J.T. 1993. Types of Flatidae: 20. Lectotype designations and taxonomic notes on species in the MNHN Paris: Part 2. (Homoptera, Fulgoroidea). Revue Française d'entomologie (Nouvelle Série) 15 (2): 49-60.

Medler J.T. 1996. Flatidae of Borneo, with descriptions of new genera and species (Homoptera: Fulgoroidea). Oriental Insects 30 (1): 11-96. https://doi.org/10.1080/00305316.1996.10433829

Medler J.T. 1999. Flatidae (Homoptera: Fulgoroidea) of Indonesia, exclusive of Irian Jaya. Zoologische Verhandelingen Leiden 324: 1-88.

Melichar L. 1902. Monographie der Acanaloniiden und Flatiden (Homoptera) (Fortsetzung). Annalen des K.K. Naturhistorischen Hofmuseums 17: 1-253.

Metcalf Z.P. 1957. General Catalogue of the Homoptera, Fascicle IV. Fulgoroidea, Part 13 Flatidae and Hypochthonellidae. North Carolina State College, Raleigh.

Stål C. 1862. Synonymiska och systematiska anteckningar öfver Hemiptera. Öfversigt af Kongliga Vetenskaps-Akademiens Förhandlingar 19: 479-504.

Stål C. 1866. Hemiptera Homoptera Latr. Hemiptera Africana 4: 1-276.

Stål C. 1870. Hemiptera insularum Philippinarum. Bidrag till Phillippinska oarues Hemiptera fauna. Öfversigt af Kongliga Vetenskaps-Akademiens Förhandlingar 27: 607-776.

Walker F. 1851. List of the Specimens of Homopterous Insects in the Collection of the British Museum, Part II. British Museum Trustees, London. https://doi.org/10.5962/bhl.title.9063

Walker F. 1858. List of the Specimens of Homopterous Insects in the Collection of the British Museum, Supplement. British Museum Trustees, London. https://doi.org/10.5962/bhl.title.9063

Zia Y. 1935. Note sur les Flatinae et les Ricaniinae de la Chine du sud et du Tonkin. Sinensia 6: 525-535.

Manuscript received: 17 November 2019

Manuscript accepted: 27 July 2020

Published on: 29 September 2020

Topic editor: Nesrine Akkari

Desk editor: Pepe Fernández

Printed versions of all papers are also deposited in the libraries of the institutes that are members of the EJT consortium: Muséum national d'histoire naturelle, Paris, France; Meise Botanic Garden, Belgium; Royal Museum for Central Africa, Tervuren, Belgium; Royal Belgian Institute of Natural Sciences, 
Brussels, Belgium; Natural History Museum of Denmark, Copenhagen, Denmark; Naturalis Biodiversity Center, Leiden, the Netherlands; Museo Nacional de Ciencias Naturales-CSIC, Madrid, Spain; Real Jardín Botánico de Madrid CSIC, Spain; Zoological Research Museum Alexander Koenig, Bonn, Germany; National Museum, Prague, Czech Republic. 